\title{
VIEWPOINTS
}

\section{Enhanced Life Expectancy during the Golden Age of Islamic Civilisation}

\author{
Daud AbdulFattah Batchelor*
}

People living in Muslim countries in 2013 had an average life expectancy at birth of just 67 years - four years lower than the global average of 71 years! Life expectancy is a statistical measure of the number of years an individual is expected to live. Global average life expectancy today is much greater than what is was in 1900 - then only 31 years. During the period of the medieval Islamic Caliphate, however, life expectancy at birth of the general population was relatively high, above 35 years, according to Conrad Lawrence (1995) in the book, The Western Medical Tradition: 800 BC to AD 1800. This is greater than longevity figures estimated for late medieval English aristocracy (30 years), and for populations in classical Greece (28 years) and classical Rome (20-30 years). Several studies even concluded that the life span of classical Muslim scholars as a professional group were between 69 and 75 years, much higher than the general population. ${ }^{1}$ Overall, the figures indicate a relatively high level of well-being for Muslim citizens during the Caliphate period. These average general figures may however, appear quite low, but in reality many citizens then lived well into their 50 s and 60 s once they survived infancy. What reduced these historical longevity figures were high infant mortality rates that existed then. The rapid increase in average life expectancy over the past 100 years is largely due to greatly reduced infant mortalities resulting from improved nutrition, water and sanitation, and the eradication of many infectious diseases, partly through child vaccinations.

The relatively long life expectancies seen for the Islamic civilisation were a direct outcome of the interwoven values contained in Islamic teachings emphasising good health and hygiene. It is well-established in modern medicine that cleanliness is essential for good health. The Prophet (Peace be upon him) stressed that "Cleanliness (tahara) is half of faith (iman)". ${ }^{2}$ This is certainly reflected in the Prophet's (Pbuh) practice and teaching of regularly bathing, cleaning teeth frequently using miswak, and wearing clean clothes. Jabir bin Abdullah (may God be pleased with him) stated that, "The Messenger of Allah (Pbuh) came to visit us, and saw a man who was wearing dirty clothes. He (Pbuh) said, "Could this person not find anything with which to wash his clothes?"3 Another time Abu Hurayrah (may God be pleased with him) narrated 
that the Messenger of Allah (Pbuh) said, "It is the duty of every Muslim to take a bath (at least) once every seven days, and to wash his head and body" ${ }^{4}$ Not only these measures but additionally the essential requirements of a practising Muslim is to bathe (ghusl) to remove major impurity (junabah), such as after conjugal relations, and to ensure ritual purity before the five-time daily prayers by taking ablutions (wudhu). These practices ensured a high level of hygiene in Islamic civilization. Consequently, as an example, Ibn Sa'id commented that "The Andalusian Muslims were very particular about their cleanliness in their person, dress, and beds and the interior of their homes. The poorest man would spend his last dirham on buying soap for washing his clothes, rather than appear in the street with dirty clothes."

Further, for Muslims, the value of life and the importance of saving lives are highly stressed in the Noble Qur'an:

We ordained for the Children of Israel that if anyone slew a person unless it be for murder or spreading mischief in the land - it would be as if he slew the whole people; and if anyone saved a life, it would be as if he saved the life of the whole people. (Q Al Maidah 5:32)

No doubt this verse has inspired Muslim physicians throughout the ages and engendered great advances in medical science by Muslim scholars. Further encouragement towards seeking good health is provided by a number of hadith including the following: Abu Hurayrah (RA) reported that the Prophet (Pbuh) said: "The strong believer is better and more beloved of Allah than the weak believer, while there is good in both." "It is clear in its usage by classical scholars such as by Ibn Taymiyyah that the connotation here includes that of physical strength. Further incitement for Islamic medical research to seek good health for the ummah were the Prophet's statements: "Every illness has a cure, and when the proper cure is applied to the disease, it heals by Allah's Will." Medical knowledge grew rapidly in the Muslim world as illustrated by the extensive tomes written by such luminaries as al-Razi, and Ibn Sina known in the West as Avicenna. Al-Qanun Fi'l-tib (the Canon of Laws in Medicine) represents the most important work of Ibn Sina, and as William Osler described it, "the most famous medical textbook ever written". ${ }^{8}$ Many medical advances claimed by western physicians actually derive from Muslim discoveries and practices, such as the explanation of pulmonary blood circulation, delayed splintage, and vaccinations, to mention a few.

Other Islamic values that are conducive towards longevity in society are seeking moderation in all things (wasatiyyah), seeking ease (taysir) rather than hardship, respecting and caring for parents in old age, maintaining family ties, taking exercise, and avoiding excessive food consumption, to name but a few. 
The relatively high life expectancy of the Caliphate period is unsurprising when considering the essential attributes of Islamic governance and administration: Rule of law providing for justice and human security; emphasis on acquiring knowledge and the provision of educational institutions; provision of clean water and sanitation systems; and treatment and caring for the ill and the aged. Extending public education is directly correlated with improved health since educated people can better access and understand health messages. The early Caliphate had (with $4^{\text {th }}$ century BC Athens) the highest literacy rates amongst pre-modern societies. ${ }^{9}$ Cities in the medieval Muslim world greatly outstripped their European counterparts with their size and public facilities.

Water is critical to the life of a Muslim from the necessity for clean drinking water and for ritual ablutions, to water used in gardens as a symbolic attribute of Paradise, while many parts of the Muslim world lie in relatively dry regions not well-endowed with reliable supplies. Consequently the hydraulic engineer was a highly respected profession and demonstrated considerable expertise and ingenuity. Surface water was transported to cities via aqueducts and canals, while underground water was tapped using deep-bored wells and qanats (gradually sloping underground channels with vertical access shafts, transporting water from aquifers). Large mosques had ablution areas and often public lavatories. Not everyone had running water, but in many cities water was carried to public fountains, and every urban quarter had bathhouses with hot and cold water on tap. ${ }^{10}$ In cities, water was stored in cisterns.

Some approaches of water supplies to Muslim cities include (1) the Umayyad capital of Cordoba in Spain ${ }^{11}$ relied upon the re-furbishing of Roman aqueducts, but with elaborate new distribution systems; (2) Fustat, the first administrative capital in Egypt after the 641-642 Islamic conquest, lying just south of Cairo, used a series of aqueducts and in the finest of houses, water was supplied through pipes into fountains and basins, often with separate supplies for potable water and for washing and cooking. ${ }^{12}$ (3) In Hama, central Syria, lifting devices tapped water from the Orontes River, which was fed through networks of underground ceramic pipes to cisterns, elegant fountains and a bathhouse.

Further, advanced sanitation systems are widely evidenced during the medieval Caliphate period. At Fustat, Egypt, even simple 2-3 room houses were each equipped with latrines sitting over cess-pits, while in high-rise multi-storey buildings, which existed then, latrines were placed on each floor with flues constructed within the walls. "In the most elaborate sanitation systems, flues from the domestic complexes were connected with underground canals, which ran into communal cesspits. Sanitation systems at Fustat suggest some forethought and subsequent management by municipal authorities, particularly in the placement of drainage channels and cesspits beyond the confines of private property". ${ }^{13}$ 
Other impressive sanitary infrastructure can be seen in 1) the former palace-city of Madinat al-Zahra, Cordoba, where it comprised 1,800 metres of subterranean channels that took water and waste from courtyards, latrines, bathhouses and roofs of buildings. These drainage routes must have been established prior to erection of the buildings. ${ }^{14}$ 2) In the congregational mosque at Mayyarfariqin in northern Mesopotamia it was reported that "the ablution pool faces forty chambers, through each of which run two large channels, one of which is visible for use, while the other is concealed beneath the earth and is for carrying away refuse and for flushing the cisterns". ${ }^{15}$

Hospitals (bimaristans) became widespread. They appeared around the $9^{\text {th }}$ century CE in Baghdad and spread quickly throughout the Muslim world. The Nuri hospital in $12^{\text {th }}$ century Damascus, had druggists, barbers, orthopedists, oculists, and physicians. Ibn Jubayr, a $12^{\text {th }}$ century traveler, observed one or more in most cities and declared that hospitals were one of "the finest proofs of the glory of Islam". ${ }^{16}$ They provided a range of facilities from treatments to convalescence to retirement residences. They looked after all kinds of people because Muslims are honour-bound to provide care for the sick. Some hospitals were specialised such as for mental patients or for leprosy treatment. Services and medicines were generally provided free-of-charge from funds from charitable religious endowments (waqf) while operating expenditures were often paid for by the government. The advanced $9^{\text {th }}$ century Ahmad ibn Tufal Hospital in Cairo contained a bathhouse each for men and women, a library, and a psychiatric wing. Patients were given ward clothes to wear and assigned beds. The $13^{\text {th }}$ century Al-Mansuri hospital in Cairo with teaching facilities had separate male and female wards with running water provided throughout. The dispensary provided medicines for patients to take home. Its founding constitution read, "[The hospital's] duty is to give care to the ill, poor, men and women, until they recover. It is at the service of the powerful and the weak, the poor and the rich ... without demand for any form of payment, but only for the sake of God, the Provider." Many hospitals doubled up as medical schools where generations of doctors - Muslim, Christian and Jewish - were trained. Here the great advances in Arabic medicine were made. ${ }^{17}$ Students often accompanied physicians on their daily rounds, examining patients' histories and preparing their prescriptions. Surgeons used advanced surgical instruments, which can be seen in today's hospitals, as described by al-Zahrawi who transformed surgery into a specialist science. The Crusaders were inspired by the magnificent hospitals of Damascus and Cairo. The first European hospital was established by Louis IX in Paris after his return from the Crusades (1254-60). ${ }^{18}$

Surprisingly however, many of the countries today that have the world's lowest life expectancies are Muslim majority countries - Afghanistan (60 years); 
Niger, Burkina Faso and Guinea (58 years); Mali (57 years); Nigeria (54 years); Somalia (53 years); Chad (50 years); and Sierra Leone (46 years; world's lowest life expectancy). At the same time these are countries that reflect high Islamicity levels in terms of praying five-times daily, paying zakat and fasting in Ramadan. ${ }^{19}$ It would appear though that inculcation of the Islamic civilisational values that lead to longevity, as discussed in this paper, have been relatively neglected here.

It is now high time for Muslims and Muslim countries to re-emphasise Islamic values and teachings so as to change the mindsets of individuals, as well as to establish institutions and facilities that engender good health, vitality and spiritual well-being (hayat al-tayyibah) for all.

\section{Notes}

* Daud AbdulFattah Batchelor, an Australian scholar, is Associate Fellow at IAIS Malaysia. He has a broad experience in industry, academia and international consulting covering the fields of Environmental Management, Islamic Political Science and Earth Sciences. He has been active in Muslim community organisations and is co-founder of the Islamic College of Brisbane. Daud has an MA in Islamic and Other Civilisations from ISTAC, and was presented the Longmans Award for $\mathrm{PhD}$ research at Universiti Malaya. He has an MSc from the Imperial College of Science and Technology, London and a Master of Engineering Science.

1. Shatzmuller, Maya. Labour in the Medieval Islamic World, (Brill Publishers, 1994), p.66.

2. Sahih Muslim (1/203), Number 223.

3. Sunan Abu Dawud, Book 32, Number 4051.

4. Al Bukhari, Book 13, Number 21.

5. Syed Azizur Rahman, The Story of Islamic Spain, (New Delhi: Goodword Books, 2001), p. 593.

6. Sahih Muslim, Number 6774. Albani called it 'hasan'.

7. Al-Bukhari, Book 71, Vol.7, Number 582.

8. William Osler, The Evolution of Modern Medicine, (Whitefish, Montana: Kessinger Publishing, 2004), p. 71.

9. Andrew J. Coulson, Delivering Education. (Stanford, California: Hoover Institution Press, c.2002), p. 117. http://www.hoover.org/sites/default/files/ uploads/documents/0817928928_105.pdf. Accessed 22/07/2015.

10. Amira K. Bennison, The Great Caliphs: The Golden Age of the 'Abbasid Empire, (Yale University Press, 2009), p. 87.

11. Cordoba was one of the world's most advanced cities in the $10^{\text {th }}$ century with paved streets and oil lamps lighting the streets after dark, amenities that London and Paris would only have 700 years later (Rageh Omar in the BBC's An Islamic History of Europe). Cordoba became a city of 500,000 population, five times larger than coeval Paris. 
12. Marcus Milwright, An Introduction to Islamic Archaeology, (Edinburgh: Edinburgh University Press, 2010), p. 93.

13. Ibid.

14. Milwright, p. 92.

15. Bennison, p. 87.

16. Salim T. S. al-Hassani (Ed.), 1001 Inventions: The Enduring Legacy of Muslim Civilization, $3^{\text {rd }}$ Edn. (Washington, D.C.: National Geographic, 2012), p. 156.

17. Bennison, p. 90.

18. Muhammad Saud. Islam and Evolution of Science (Islamabad: Islamic Research Institute, International Islamic University, 1986).

19. Daud A. F. Batchelor, "A New Islamic Rating Index of Well-being for Muslim Countries", Islam and Civilisational Renewal, Vol. 4(2), 2013, pp. 188-214. 